\title{
Immediate implant placement in fresh extraction sockets
}

\author{
Won Lee \\ Department of Dentistry, Uijeongbu St. Mary's Hospital, College of Medicine, The Catholic University of Korea, Seoul, Korea
}

\begin{abstract}
J Korean Assoc Oral Maxillofac Surg 2021;47:57-61)
Immediate implant placement (IIP) in fresh extraction sockets exhibits similar survival and success rates to delayed implant placement in healed sockets. Several advantages of IIP involve shortened total treatment time, reduction of the number of invasive surgeries, and subsequent reduction of patient discomfort due to lack of additional surgeries. The major shortcomings in IIP, however, include the inability to obtain early bony support, presence of a gap between the extraction socket and fixture, and the inability to cover the fixture with soft tissue, leading to increased risk of infection and implant loss. When IIP is performed, atraumatic or minimally traumatic extractions, conservation of the septal bone in molars, minimal flap elevation or flapless surgery, bone grafting the gap between the fixture and the extraction socket, and coverage with soft tissue or a membrane must be considered.
\end{abstract}

Key words: Immediate implant placement, Tooth socket, Tooth extraction

[paper submitted 2021. 2. 8 / accepted 2021. 2. 9]

\section{Introduction}

Since implant therapy has become one of the most important dental procedures, many techniques for implant placement and timing of implant installation have been studied and developed. Popular studies have centered around implant placement timing as well as immediate placement in fresh extraction sockets ${ }^{1-3}$.

In implant therapy, the waiting period for osseointegration has always been an issue. In cases of tooth extraction, additional time is required to place an implant after waiting for the alveolar ridge to heal normally, and efforts to reduce this waiting period have been studied.

Bone loss during healing of the extraction socket, especially marginal bone loss due to absorption of the thin buccal plate, should be resolved not only for esthetics, but also for bone height loss ${ }^{4}$.

The advantages of immediate implant placement (IIP) in

\section{Won Lee}

Dental Clinic, Uijeongbu St. Mary's Hospital, 271 Cheonbo-ro, Uijeongbu 11765, Korea

TEL: +82-31-820-3574

E-mail:cmfs21@yahoo.com

ORCID: https://orcid.org/0000-0002-6383-8754

(c) This is an open-access article distributed under the terms of the Creative Commons Attribution Non-Commercial License (http://creativecommons.org/ licenses/by-nc/4.0/), which permits unrestricted non-commercial use, distribution, and reproduction in any medium, provided the original work is properly cited.

Copyright (C) 2021 The Korean Association of Oral and Maxillofacial Surgeons. All rights reserved. fresh extraction sockets is that the total treatment time can be shortened, the number of invasive surgeries can be reduced, and patient discomfort can be reduced due to fewer surgeries.

Immediate placement has been reported to exhibit similar survival and success rates to delayed implant placement after socket healing ${ }^{5-7}$. However, other systematic reviews and meta-analysis studies have reported lower survival rates of IIP in fresh extraction sockets compared to delayed implant placement in healed sockets ${ }^{8}$.

The basic principles of IIP are atraumatic or minimally traumatic extraction, conservation of the septal bone in molar, minimal flap elevation or flapless surgery, bone grafting the gap between the fixture surface and the inner wall of the extraction socket, and coverage with soft tissue or a membrane when possible.

\section{Choice of Implant Fixture Surface}

At a fixture surface, a hydroxyapatite (HA)-coated implant fixture can be used to increase initial stability. However, if initial stability can be obtained from the apical or lateral bone of the extraction socket, the type of fixture surface is less important. 


\section{Atraumatic or Minimally Traumatic Extraction}

The main reason for performing extraction atraumatically is to preserve maximal bone quality and obtain initial stability. During IIP, bony support typically is obtained from apical or lateral bone, but is often obtained from septal bone in posterior extraction sockets. Atraumatic extraction can minimize gingival recession and marginal bone loss, which often result from extraction, leading to esthetic and functional advantages.

\section{Position of Implant Fixture Placement}

Unlike implant positioning in healed sockets on the alveolar ridge, positioning of immediate implants is generally at the lingual or palatal aspect of the extraction socket. Severe bone resorption occurs at the buccal/facial plate that is thinner than the lingual or palatal socket wall'. The reason for implant placement on the palatal/lingual aspect is to prevent thread exposure of the placed implant from resorption of the buccal plate.

In cases of anterior teeth, an indentation is created at the coronal one-third of the palatal socket wall for drilling. Most of the lingual or palatal surfaces of the implant fixture are in contact with the alveolar bone, but the facial surface of the fixture typically is exposed within the socket and forms a gap with the buccal wall.

Unlike studies on drilling in healed alveolar ridges, many studies on implant placement in extraction sockets have focused on single-rooted teeth such as premolars and those found in the esthetic zone $\mathrm{e}^{10-12}$. However, in recent years, many studies on IIP in fresh extraction sockets of molars have been performed $^{13-15}$.

In molars, fresh extraction sockets have no remaining bone due to enlargement or inflammation of roots. As a result, implants cannot obtain bone support for fixture stability. Socket preservation techniques and/or bone augmentation procedures around implants are being performed with guided bone regeneration to solve this issue. However, if graft material is exposed or infected, augmentation failure or implant failure can occur.

Fixture stability in molars can be secured using apical bone and, if possible, septal bone. The mandibular molars have mesial and distal roots, so the septal bone contacts the buccal and lingual surfaces of the fixture, with a gap at mesial and distal aspects of the fixture. If the location of implant place- ment permits, contact with the mesial wall of the extraction socket and fixture is established to obtain fixture support not only from the septal bone, but also from the socket wall of the mesial root. In maxillary molars, since the teeth have 3 roots, the septal bone holds the fixture in 3 directions. Greater stability can be obtained from the septal bone between the palatal root than from the septal bone between the mesiobuccal and distobuccal roots.

As bone resistance is not the same on all sides, there is a high possibility of drilling in an unwanted direction. Therefore, correct indentation and proper use of side cutting burs are critical to prevent errors during drilling and to form fixture holes.

\section{Depth of Implant Fixture Placement}

Anterior teeth can cause esthetic issues through resorption of a fresh extraction socket. Therefore, the fixture should be placed deep during the IIP. In general, marginal bone loss of approximately $1 \mathrm{~mm}$ is expected, and when a flap is not elevated, the bony crest begins $3 \mathrm{~mm}$ beneath the soft tissue. Therefore, most implant placement in the esthetic zone is $4 \mathrm{~mm}$ beneath the soft tissue. In posterior teeth, bone loss is expected, and implants should be placed more than $1 \mathrm{~mm}$ deeper than the alveolar crest.

Unlike implants in the edentulous ridge where stability is mainly obtained from the alveolar crest, support of IIP fixtures must be obtained from septal bone or bone below the apex of the socket. Therefore, immediate implants should be placed with a slightly longer fixture than those used in delayed placement ${ }^{16}$. If support of the septal bone is not sufficient, the fixture that should long enough to obtain bony fixation of $4 \mathrm{~mm}$ or more beneath the apex.

Since delayed implants are fixed in the cervical area of the cortical bone, a drill with a diameter suitable for the proper sequence can be used. IIP fixation by cortical bone obtained at the apical cortex in the extraction socket differs from fixation in healed sockets. Therefore, drilling during IIP should be performed carefully.

If the fixture is cylindrical in shape, a straight twist drill can be used. However, when a root-shaped fixture is used, a tapered drill or lower 1-2 step twist drills must be used for sufficient fixation.

\section{Flap Elevation for Implant Placement}

Flapless surgery rather than flap elevation is usually per- 
formed for IIP. If performed without bone grafting, this can lead to bone resorption of peri-implant alveolar bone ${ }^{17,18}$. In the flap elevation technique, marginal bone loss will occur because the blood supply from the buccal gingiva is disrupted due to flap elevation on the thin buccal bone plate and the blood supply from the socket is stopped by the extraction. Noelken et al. ${ }^{19}$ reported that autogenous bone grafting with the flapless technique affects marginal bone level, with slight apical bone reduction at the implant shoulder without esthetic issues.

\section{Bone Augmentation}

If the gap between the fresh extraction socket and fixture is wide, bone augmentation is performed at the IIP site in fresh extraction sockets.

Placement of bone grafting material in the gap between the implant and the buccal bone walls of fresh extraction sockets influences hard tissue healing and decreases marginal bone $\operatorname{loss}^{20,21}$. Bone grafting at the gap is recommended to improve bone contact to the implant surface and decrease gingival recession resulting from horizontal bone resorption ${ }^{22-24}$. Although, there is not enough evidence supporting the need for augmentation at the gaps and the kinds of augmentation procedures $^{25}$, many studies have shown that bone grafting improves implant survival and success rates ${ }^{15}$.

\section{Covering the Gap with a Membrane}

When bone graft is placed in the gap, a membrane or soft tissue is needed to cover the exposed grafting material. For soft tissue covering, the flap is elevated, and a releasing incision is created. The flapless technique is used often because the blood flow of the labial flap is interrupted by flap elevation.

If implant placement is flapless, the fixture cannot be submerged. For this reason, a non-resorbable high-density polytetrafluoroethylene membrane ${ }^{26}$ or resorbable collagen membrane ${ }^{27}$ is used. When non-resorbable membranes are used, a secondary surgery is required, increasing patient inconvenience. Therefore, most resorbable membranes are made of collagen or are synthetic in nature ${ }^{28}$. In recent years, platelet-rich fibrin (PRF) has been used to maintain graft material between the gaps and allows quick soft tissue coverage $^{29}$. PRF is an autologous biomaterial that not only effects cell proliferation, cell migration, and angiogenesis, but also possesses anti-inflammatory properties in vitro ${ }^{30}$.

\section{Infected Sockets}

In cases of extraction due to lesions such as chronic periodontitis or periapical lesions, the socket can become infected. Therefore, it is common to proceed with conventional implant placement after socket healing ${ }^{31}$. However, if the size of the lesion is not large or if infection is properly controlled by antibiotics, IIP is possible ${ }^{32}$. IIP can be performed after the inside of the infected socket is sufficiently curetted and irrigated profusely with saline ${ }^{33}$.

It is necessary to sufficiently explain to the patient the possibility of osseointegration failure due to an infected socket to obtain informed consent ${ }^{34}$.

\section{Disadvantages of IIP}

The major shortcomings of IIP are the inability to obtain early bony support with a gap between the extraction socket and the fixture, lack of soft tissue covering with possible deficiencies in the peri-implant keratinized gingiva, and increased risk of infection and implant loss ${ }^{25}$.

\section{Summary}

1. IIP has the advantage of reducing traumatic surgery to patients by placing implants during the same procedure as tooth extraction.

2. IIP does not require healing time of the extraction socket, so the overall treatment period is shortened.

3. By preserving the extraction socket as much as possible, IIP can be aesthetically pleasing when fabricating a prosthesis.

4. Atraumatic extraction should be performed to maintain the original socket form.

5. It is possible to minimize collapse of the socket by bone grafting in the gap.

6. It is advantageous to use a flapless technique to preserve the blood supply to the thin buccal bone plate of the extraction socket.

7. A resorbable membrane with PRF should be used as a cover to protect the graft material between the implant surface and bony socket wall and well cover the soft tissue.

\section{Author's Contributions}

The manuscript was written by W.L. 


\section{Conflict of Interest}

No potential conflict of interest relevant to this article was reported.

\section{References}

1. Lang NP, Pun L, Lau KY, Li KY, Wong MC. A systematic review on survival and success rates of implants placed immediately into fresh extraction sockets after at least 1 year. Clin Oral Implants Res 2012;23 Suppl 5:39-66. https://doi.org/10.1111/j.16000501.2011.02372.x

2. den Hartog L, Slater JJ, Vissink A, Meijer HJ, Raghoebar GM. Treatment outcome of immediate, early and conventional singletooth implants in the aesthetic zone: a systematic review to survival, bone level, soft-tissue, aesthetics and patient satisfaction. J Clin Periodontol 2008;35:1073-86. https://doi.org/10.1111/j.1600051X.2008.01330.x

3. Canellas JVDS, Medeiros PJD, Figueredo CMDS, Fischer RG, Ritto FG. Which is the best choice after tooth extraction, immediate implant placement or delayed placement with alveolar ridge preservation? A systematic review and meta-analysis. J Craniomaxillofac Surg 2019;47:1793-802. https://doi.org/10.1016/ j.jcms.2019.08.004

4. Schropp L, Wenzel A, Spin-Neto R, Stavropoulos A. Fate of the buccal bone at implants placed early, delayed, or late after tooth extraction analyzed by cone beam CT: 10-year results from a randomized, controlled, clinical study. Clin Oral Implants Res 2015;26:492-500. https://doi.org/10.1111/clr.12424

5. Gökçen-Röhlig B, Meriç U, Keskin H. Clinical and radiographic outcomes of implants immediately placed in fresh extraction sockets. Oral Surg Oral Med Oral Pathol Oral Radiol Endod 2010;109:e1-7. https://doi.org/10.1016/j.tripleo.2009.11.030

6. Malchiodi L, Balzani L, Cucchi A, Ghensi P, Nocini PF. Primary and secondary stability of implants in postextraction and healed sites: a randomized controlled clinical trial. Int J Oral Maxillofac Implants 2016;31:1435-43. https://doi.org/10.11607/jomi.4710

7. Schropp L, Wenzel A, Stavropoulos A. Early, delayed, or late single implant placement: 10-year results from a randomized controlled clinical trial. Clin Oral Implants Res 2014;25:1359-65. https://doi. org $/ 10.1111 /$ clr. 12273

8. Mello CC, Lemos CAA, Verri FR, Dos Santos DM, Goiato MC, Pellizzer EP. Immediate implant placement into fresh extraction sockets versus delayed implants into healed sockets: a systematic review and meta-analysis. Int J Oral Maxillofac Surg 2017;46:1162-77. https://doi.org/10.1016/j.ijom.2017.03.016

9. Chen ST, Darby I. The relationship between facial bone wall defects and dimensional alterations of the ridge following flapless tooth extraction in the anterior maxilla. Clin Oral Implants Res 2017;28:931-7. https://doi.org/10.1111/clr.12899

10. Buser D, Chappuis V, Belser UC, Chen S. Implant placement post extraction in esthetic single tooth sites: when immediate, when early, when late? Periodontol 2000 2017;73:84-102. https://doi. org/10.1111/prd. 12170

11. Tonetti MS, Cortellini P, Graziani F, Cairo F, Lang NP, Abundo R, et al. Immediate versus delayed implant placement after anterior single tooth extraction: the timing randomized controlled clinical trial. J Clin Periodontol 2017;44:215-24. https://doi.org/10.1111/ jepe. 12666

12. Amato F, Polara G, Spedicato GA. Tissue dimensional changes in single-tooth immediate extraction implant placement in the esthetic zone: a retrospective clinical study. Int J Oral Maxillofac Implants 2018:33:439-47. https://doi.org/10.11607/jomi.6146
13. Ketabi M, Deporter D, Atenafu EG. A systematic review of outcomes following immediate molar implant placement based on recently published studies. Clin Implant Dent Relat Res 2016;18:1084-94. https://doi.org/10.1111/cid.12390

14. Noelken R, Pausch T, Wagner W, Al-Nawas B. Peri-implant defect grafting with autogenous bone or bone graft material in immediate implant placement in molar extraction sites-1- to 3-year results of a prospective randomized study. Clin Oral Implants Res 2020;31:1138-48. https://doi.org/10.1111/clr.13660

15. Ragucci GM, Elnayef B, Criado-Cámara E, Del Amo FS, Hernández-Alfaro F. Immediate implant placement in molar extraction sockets: a systematic review and meta-analysis. Int J Implant Dent 2020;6:40. https://doi.org/10.1186/s40729-020-00235-5

16. Gupta G, Gupta DK, Gupta N, Gupta P, Rana KS. Immediate placement, immediate loading of single implant in fresh extraction socket. Contemp Clin Dent 2019;10:389-93. https://doi. org/10.4103/ccd.ccd_565_18

17. Botticelli D, Berglundh T, Lindhe J. Hard-tissue alterations following immediate implant placement in extraction sites. J Clin Periodontol 2004;31:820-8. https://doi.org/10.1111/j.1600051X.2004.00565.x

18. Ferrus J, Cecchinato D, Pjetursson EB, Lang NP, Sanz M, Lindhe $\mathrm{J}$. Factors influencing ridge alterations following immediate implant placement into extraction sockets. Clin Oral Implants Res 2010;21:22-9. https://doi.org/10.1111/j.1600-0501.2009.01825.x

19. Noelken R, Moergel M, Kunkel M, Wagner W. Immediate and flapless implant insertion and provisionalization using autogenous bone grafts in the esthetic zone: 5-year results. Clin Oral Implants Res 2018;29:320-7. https://doi.org/10.1111/clr.13119

20. Araújo MG, Linder E, Lindhe J. Bio-Oss collagen in the buccal gap at immediate implants: a 6-month study in the dog. Clin Oral Implants Res 2011;22:1-8. https://doi.org/10.1111/j.16000501.2010.01920.x

21. Sanz M, Lindhe J, Alcaraz J, Sanz-Sanchez I, Cecchinato D. The effect of placing a bone replacement graft in the gap at immediately placed implants: a randomized clinical trial. Clin Oral Implants Res 2017;28:902-10. https://doi.org/10.1111/clr.12896

22. Cardaropoli D, Tamagnone L, Roffredo A, De Maria A, Gaveglio L. Preservation of peri-implant hard tissues following immediate postextraction implant placement. Part I: radiologic evaluation. Int J Periodontics Restorative Dent 2019;39:633-41. https://doi. org/10.11607/prd.4183

23. Kan JYK, Rungcharassaeng K, Deflorian M, Weinstein T, Wang HL, Testori T. Immediate implant placement and provisionalization of maxillary anterior single implants. Periodontol 2000 2018;77:197-212. https://doi.org/10.1111/prd.12212

24. Clementini M, Agostinelli A, Castelluzzo W, Cugnata F, Vignoletti F, De Sanctis M. The effect of immediate implant placement on alveolar ridge preservation compared to spontaneous healing after tooth extraction: radiographic results of a randomized controlled clinical trial. J Clin Periodontol 2019;46:776-86. https://doi. org/10.1111/jcpe. 13125

25. Esposito M, Grusovin MG, Polyzos IP, Felice P, Worthington HV. Interventions for replacing missing teeth: dental implants in fresh extraction sockets (immediate, immediate-delayed and delayed implants). Cochrane Database Syst Rev 2010;(9):CD005968. https:// doi.org/10.1002/14651858.CD005968.pub3

26. Zafiropoulos GG, Kasaj A, Hoffmann O. Immediate implant placement in fresh mandibular molar extraction socket: 8-year results. A case report. J Oral Implantol 2010;36:145-51. https://doi. org/10.1563/AAID-JOI-D-09-00030

27. Cafiero C, Annibali S, Gherlone E, Grassi FR, Gualini F, Magliano A, et al.; ITI Study Group Italia. Immediate transmucosal implant placement in molar extraction sites: a 12-month prospective multicenter cohort study. Clin Oral Implants Res 2008;19:476-82. https://doi.org/10.1111/j.1600-0501.2008.01541.x

28. Hämmerle $\mathrm{CH}$, Lang NP. Single stage surgery combining transmu- 
cosal implant placement with guided bone regeneration and bioresorbable materials. Clin Oral Implants Res 2001;12:9-18. https:// doi.org/10.1034/j.1600-0501.2001.012001009.x

29. Sun XL, Mudalal M, Qi ML, Sun Y, Du LY, Wang ZQ, et al. Flapless immediate implant placement into fresh molar extraction socket using platelet-rich fibrin: a case report. World J Clin Cases 2019;7:3153-9. https://doi.org/10.12998/wjcc.v7.i19.3153

30. Mudalal M, Sun X, Li X, Zhou Y. The evaluation of leukocyteplatelet rich fibrin as an anti-inflammatory autologous biological additive. A novel in vitro study. Saudi Med J 2019;40:657-68. https://doi.org/10.15537/smj.2019.7.24302

31. Hämmerle CH, Chen ST, Wilson TG Jr. Consensus statements and recommended clinical procedures regarding the placement of implants in extraction sockets. Int J Oral Maxillofac Implants 2004;19 Suppl:26-8.

32. Novaes AB Jr, Papalexiou V, Grisi MF, Souza SS, Taba M Jr, Kajiwara JK. Influence of implant microstructure on the osseoin- tegration of immediate implants placed in periodontally infected sites. A histomorphometric study in dogs. Clin Oral Implants Res 2004;15:34-43. https://doi.org/10.1046/j.1600-0501.2003.00968.x

33. Lee J, Park D, Koo KT, Seol YJ, Lee YM. Comparison of immediate implant placement in infected and non-infected extraction sockets: a systematic review and meta-analysis. Acta Odontol Scand 2018;76:338-45. https://doi.org/10.1080/00016357.2018.1453084

34. McCracken MS, Chavali RV, Al-Naief NS, Eleazer PD. A residual granuloma in association with a dental implant. Implant Dent 2012;21:87-90. https://doi.org/10.1097/ID.0b013e31824c2b52

How to cite this article: Lee W. Immediate implant placement in fresh extraction sockets. J Korean Assoc Oral Maxillofac Surg 2021;47:57-61. https://doi.org/10.5125/jkaoms.2021.47.1.57 